\title{
Physiological and Biochemical Responses to Ozone Toxicity in Five Species of genus Quercus Seedlings
}

\author{
Du-Hyun Kim ${ }^{1 *}$, Sim-Hee Han ${ }^{1}$, Ja-Jung Ku${ }^{1}$, Kab-Yeon Lee ${ }^{1}$ and Pan-Gi Kim ${ }^{2}$ \\ ${ }^{1}$ Divison of Forest Genetic Resources, Korea Forest Research Institute, Suwon, 441-350, Korea \\ ${ }^{2}$ Division of Forest Environment and Resources, Kyungpook National University, Sangju, 742-711, Korea \\ (Received May 7, 2008; Revised June 13, 2008; Accepted June 25, 2008)
}

\section{참나무속 5 종의 오존 독성에 대한 생리생화학적 반응}

\author{
김두현 ${ }^{*} \cdot$ 한심희 ${ }^{1} \cdot$ 구자정 $^{1} \cdot$ 이갑연 ${ }^{1} \cdot$ 김판기 ${ }^{2}$ \\ 1국립산림과학원 산림유전자원부, ${ }^{2}$ 경북대학교 산림환경자원학부 \\ (2008년 5월 7일 접수; 2008년 6월 13일 수정; 2008년 6월 25일 수락)
}

\begin{abstract}
Physiological and biochemical changes of five species of genus Quercus exposed to ozone fumigation were investigated to assess their tolerance against ozone toxicity. At the end of $150 \mathrm{ppb}$ ozone fumigation, chlorophyll contents, photosynthetic characteristics, malondialdehyde (MDA) and antioxidative enzyme activities were measured in the leaves of five Quercus species (Quercus acutissima, $Q$. aliena, $Q$. palustris, $Q$. serrata, and $Q$. variabilis). Chlorophyll and carotenoid contents, net photosynthesis and carboxylation efficiency decreased after ozone treatment, indicating that $\mathrm{O}_{3}$-exposed plants underwent physiological inhibition. The reduction rate of total chlorophyll contents and carboxylation efficiency were respectively $15 \%$ and $34 \%$ for $Q$. aliena and $38 \%$ and $62 \%$ for $Q$. variabilis. The amount of MDA increased with the highest increase rate of $140 \%$ in $Q$. acutissima which also showed the highest increase rate $(60 \%)$ of superoxide dismutase (SOD). Ascorbate peroxidase (APX) activity increased in $Q$. variabilis, $Q$. serrata and $Q$. acutissima by ozone treatment. Based on our results, ozone tolerance of the five Quercus species was ranked as $Q$. aliena $>Q$. palustris $>Q$. serrata $>Q$. variabilis $>Q$. acutissima. We concluded that chlorophyll contents, photosynthesis, MDA content and antioxidative enzymes were the important physiological markers for tolerance against ozone stress, which were closely related with one another.
\end{abstract}

Key words : Oak, Chlorophyll content, Photosynthesis, MDA, Antioxidative enzyme

\section{INTRODUCTION}

For more than 50 years, the phytotoxicity of ozone $\left(\mathrm{O}_{3}\right)$ has been demonstrated for forest tree species (Karnosky et al., 2007). Studies concerning the dynamics of ozone $\left(\mathrm{O}_{3}\right)$ between atmosphere and plants have been carried out under the United Nations Economic Commission for Europe-Convention on Long Range Transboundary Air Pollution (UNECE CLRTAP) (Mills et $a l ., 2000)$. It is now clearly established that $\mathrm{O}_{3}$ can cause a range of effects including visible leaf injury and reduction of growth and yield, and can alter the sensitivity of plants to biotic and abiotic stresses (Fuhrer and Achermann, 1994). Despite the increasing environmental awareness and regulations designed to limit industrial and vehicular emissions, ozone levels potentially harmful to human health and vegetation have increased every year in Korea (Ministry of Environment, 2005).

Oak trees, Quercus species, which are one of the

Corresponding Author: Du-Hyun Kim (dhkim@forest.go.kr) 
most abundant tree species in Korean, are important economically and ecologically as the ornamental or roadside tree. They are known as a tolerance species to air pollutants, but the information on the biochemical and physiological responses and tolerant mechanisms for Quercus species under environmental stress was few.

It appears that distinct $\mathrm{O}_{3}$ induced effects are largely confined to fast-growing tree species (Skärby et al., 1998). Investigations on the effects of $\mathrm{O}_{3}$ on the slowgrown species, such as Quercus, are scarce and did not consider $\mathrm{O}_{3}$ to be a significant factor in the complex of damage to the oak (Thomas et al., 2002, Samuelson et al., 1996; Hanson et al., 2005). On the other hand, Hanson et al. (1994) and Kelting et al. (1995) reported reductions in foliar assimilation to $\mathrm{O}_{3}$ exposures in red oak (Q. rubra). No information has been provided to compare the sensitivity among Quercus species to $\mathrm{O}_{3}$ that this study focuses on. However, difficulties in ranking the $\mathrm{O}_{3}$ sensitivity of different species may arise since intra-specific variations have been reported in several plant species (Inclán et al., 1999; Minnocci et al., 1999; Ranieri et al., 2001). Inclán et al. (1999) indicated the differential sensitivity to $\mathrm{O}_{3}$ of five Mediterranean woody species, and Elvira et al. (2004) reported intra-specific variations in two population of $Q$. coccifera to $\mathrm{O}_{3}$.

During the past three decades, occurrence of oak declines has been recorded in many European countries (Thomas et al., 2002). In the Mediterranean region, mainly $Q$. ilex has been affected (Müller-Edzards et al., 1997), and a decline has been also reported for deciduous oak species $(Q$. cerris, $Q$. frainetto, $Q$. pubescens and $Q$. robur) in Italy (Ragazzi et al., 1998), and for $Q$. suber on the Iberian Peninsula (Sousa Santos and Moura Martins, 1993). On the contrary, studies of red oak, however, showed an enhanced sensitivity to $\mathrm{O}_{3}$ in 30 -year-old mature trees than two year-old seedlings due to higher stomatal conductances in the older trees (Samuelson et al., 1996; Weinstein et al., 1998; Wullschleger et al., 1996).

The factors determining plant sensitivity or tolerance are not clearly understood but it is thought to be related to many underlying physiological, anatomical, biochemical and environmental factors (Alonso et al., 2001; Pääkkönen et al., 1998, Ribas et al., 2005). Ozone effects on tree biomass are the result of several processes occurring at the cellular and physiological levels. Acceleration of leaf senescence has been widely reported as one of the most characteristic processes derived form ozone exposure. These processes involve chlorophyll degradation and reductions in $\mathrm{CO}_{2}$ assimilation (Elvira et al., 1998; Zheng et al., 2002). Physiological effects of ozone exposure include photosynthesis reduction and an increase of antioxidant systems. Photosynthesis reduction results in a decreased growth rate in either volume or biomass.

The biochemical markers have been used to select the best tolerant species, cultivar and variety to $\mathrm{O}_{3}$ or other pollutants (Han et al., 2006). Paoletti et al. (2003) also adopted antioxidant levels as biomarkers of ozone sensitivity that could be used for screening of great diversity of tree species' potential sensitivity to ozone. However, there was not an exact answer about the differences of biochemical and physiological responses among species, cultivar or varieties as well as among biochemical makers.

Therefore, this study was undertaken to investigate cellular responses to ozone as mechanism for oxidant impact on photosynthesis in seedlings of oak trees. The aims of the present study were to (1) determine the effects of ozone exposure on photosynthetic pigments, photosynthesis, antioxidant enzyme activities and lipid peroxidation, (2) evaluate the potential occurrence of interspecific variations in $\mathrm{O}_{3}$ sensitivity in Quercus, and (3) evaluate a differential sensitivity to ozone exposure in Quercus.

\section{MATERIALS AND METHODS}

Seeds of five species of genus Quercus (Q. acutissima, $Q$. aliena, $Q$. palustris, $Q$. serrata, and $Q$. variabilis) were germinated in sand soil on March 12, 2007. One-year-old seedlings were transplanted into plastic pots $(\mathrm{H} 20 \times \mathrm{W} 15 \mathrm{~cm})$ containing artificial soil which consisted of 1:1:1 sand: peat moss: vermiculite (volume basis). Five seedlings per treatment were transferred into $\mathrm{O}_{3}$ chamber and were arranged in two blocks. $\mathrm{O}_{3}$ treatment was divided into two chambers: control chamber was circulated with the clean air and the other one was fumigated with 150 ppb $\mathrm{O}_{3} . \mathrm{O}_{3}$ fumigation time was $8 \mathrm{hrs}$ a day. $\mathrm{O}_{3}$ concentration in chamber was registered $5 \pm 1$ ppb in control and $150 \pm 10 \mathrm{ppb}$ in treatment chamber during fumigation period. The fumigation system has been described in detail by Lee et al. (2003). The experiment was started on June 22, 2007 and it was conducted for four weeks. 


\subsection{Photosynthetic pigments}

At the end of $\mathrm{O}_{3}$ fumigation, the leaves of control and $\mathrm{O}_{3}$-treated seedling of oak trees were excised and soaked in dimethyl sulfoxide (DMSO) in a glass vial. The vial was tightly capped and incubated at $70{ }^{\circ} \mathrm{C}$ for $2 \mathrm{hrs}$ in the dark. The concentration of the extracted pigments (total chlorophyll, chlorophyll a, chlorophyll $b$ and carotenoid) was calculated on the basis of their absorbance values at 664,645 and $470 \mathrm{~nm}$ according to Lichtenthaler (1987).

\subsection{Photosynthesis and biomass}

Net photosynthesis of fully expanded leaves was measured with an infrared gas analyzer (Li-6400, LiCOR, USA). Environmental parameters were maintained stably for measuring (mean temperature: $20.0 \pm$ $0.1{ }^{\circ} \mathrm{C}$; relative humidity: $68.2 \pm 3.2 \%$; leaf-to-air vapour pressure deficit: $1.2 \pm 0.2 \mathrm{kPa}$ ). All determinations were performed at $1100 \mu \mathrm{mol} \mathrm{m}{ }^{-2} \mathrm{~s}^{-1}$ photon flux density (PFD). Net photosynthesis (A, $\mu \mathrm{mol} \mathrm{CO} \mathrm{CO}_{2} \mathrm{~m}^{-2} \mathrm{~s}^{-1}$ ) was determined at light saturation level between 10 a.m. and 3 p.m.

To calculate carboxylation efficiency, $A C i$-curve was made (Farquhar et al., 1980; Kim and Lee, 2001). The carboxylation efficiency was determined from the initial slope of a linear regression using the linear portion of the $A C i$-curve (0-150 ppb intercellular $\mathrm{CO}_{2}$ ).

For biomass measurements, shoots and roots were carefully removed, and then thoroughly rinsed twice with distilled water. Shoot and root dry weights were recorded after drying the tissues at $70{ }^{\circ} \mathrm{C}$.

\subsection{Lipid peroxidation}

Lipid peroxidation was determined by measuring the amount of malondialdehyde (MDA) produced by thiobarbituric acid reaction as described by Heath and Parker (1968). The crude extract was mixed with the same volume of $0.5 \%(\mathrm{w} / \mathrm{v})$ thiobarbituric acid solution containing $20 \%(\mathrm{w} / \mathrm{v})$ trichloroacetic acid. The mixture was heated at $95{ }^{\circ} \mathrm{C}$ for $30 \mathrm{~min}$. and then quickly cooled in an ice-bath. The mixture was centrifuged at $3000 \times \mathrm{g}$ for $10 \mathrm{~min}$. and the absorbance of the supernatant was monitored at 532 and $600 \mathrm{~nm}$. After subtracting the non-specific absorbance $(600 \mathrm{~nm})$, MDA concentration was determined by its molar extinction coefficient $\left(155 \mathrm{mM}^{-1} \mathrm{~cm}^{-1}\right)$ and the results were expressed as $\mu$ mol MDA $\mathrm{g}^{-1} \mathrm{FW}$.

\subsection{Antioxidative enzyme activities}

Fresh leaves $(0.1 \mathrm{~g})$ were homogenized under ice- cold condition with $5 \mathrm{~mL}$ of $50 \mathrm{mM}$ phosphate buffer (pH 7.0), $10 \mathrm{mM}$ ascorbic acid (AsA) and 1.0\% (w/v) polyvinylpyrrolidone. The homogenate was centrifuged at $20,000 \times \mathrm{g}$ for $30 \mathrm{~min}$. and the supernatant was collected for enzyme assays.

Superoxide dismutase (SOD) was assayed based on the inhibition of reduction of nitro-blue tetrazolium in the presence of xanthine at $530 \mathrm{~nm}$ according to the method of Beauchamp and Fridovich (1971). Ascorbate peroxidase (APX) activity was determined by the method of Nakano and Asada (1981). The assay was carried out in a reaction mixture containing $50 \mathrm{mM}$ phosphate buffer ( $\mathrm{pH} 7.0$ ), $0.5 \mathrm{mM}$ AsA, $0.1 \mathrm{mM}$ EDTA, $0.1 \mathrm{mM} \mathrm{H}_{2} \mathrm{O}_{2}$, and $0.1 \mathrm{~mL}$ enzyme extract. The change in $\mathrm{A}_{290}$ was recorded for $1 \mathrm{~min}$. after the addition of $\mathrm{H}_{2} \mathrm{O}_{2}$. Activity of glutathione reductase (GR) was assayed as described in Carlberg and Mannervik (1985). The assay was carried out in a reaction mixture containing $50 \mathrm{mM}$ phosphate buffer ( $\mathrm{pH} 7.8), 0.1 \mathrm{mM}$ NADPH, $0.5 \mathrm{mM}$ GSSH and $0.1 \mathrm{~mL}$ enzyme extract. The change in $\mathrm{A}_{340}$ was recorded for $5 \mathrm{~min}$. after the addition of enzyme extract. Catalase (CAT) activity was determined by following a two-step procedure (Fossati et al., 1980). The rate of dismutation of $\mathrm{H}_{2} \mathrm{O}_{2}$ to water and molecular oxygen is proportional to the concentration of catalase. Therefore, the sample containing catalase was incubated in the presence of a known concentration of $\mathrm{H}_{2} \mathrm{O}_{2}$. After incubation for exactly one minute, the reaction was quenched with sodium azide. The amount of $\mathrm{H}_{2} \mathrm{O}_{2}$ remaining in the reaction mixture was then determined by the oxidative coupling reaction of 4-aminophenazone (4-aminoantipyrene) and 3,5-dichloro-2-hydroxybenzenesulfonic acid (DHBS) in the presence of $\mathrm{H}_{2} \mathrm{O}_{2}$ and catalyzed by horseradish peroxidase (HRP). The resulting quinoneimine dye was measured at $520 \mathrm{~nm}$. All enzyme activities were measured using UV-120 (SHIMADZU, Japan).

\subsection{Tolerance and injury index}

Based on physiological and biochemical responses, ozone tolerance ability of five Quercus species was ranked. Injury index was determined by the effect of ozone on MDA, total chlorophyll content, carboxylation efficiency and biomass. Tolerance index was calculated using increase rate of SOD, APX, CAT and GR activities. Standard index on each parameter was calculated as $(\mathrm{X}-\mathrm{Xavg}) / \mathrm{SD}$, where $\mathrm{X}$ is the average difference rate between control and ozone treatment for each species, Xavg is the average difference rate between 
Table 1. Effects of ozone fumigation on photosynthetic pigments in the leaves of five species of genus Quercus

\begin{tabular}{|c|c|c|c|c|c|c|c|}
\hline \multirow{2}{*}{ Species } & \multirow{2}{*}{ Ozone } & Chl a & Chl b & $C h l_{a+b}$ & Car & \multirow{2}{*}{$C h l \mathrm{a} / \mathrm{b}$} & \multirow{2}{*}{ Chl/Car } \\
\hline & & \multicolumn{4}{|c|}{$\mathrm{mg} \mathrm{g}^{-1}$} & & \\
\hline \multirow{3}{*}{ Q. acutissima } & Control & $3.77 \pm 0.02$ & $1.81 \pm 0.02$ & $5.58 \pm 0.03$ & $0.86 \pm 0.01$ & $2.08 \pm 0.02$ & $6.50 \pm 0.05$ \\
\hline & $150 \mathrm{ppb}$ & $2.49 \pm 0.01$ & $1.46 \pm 0.02$ & $3.95 \pm 0.03$ & $0.68 \pm 0.10$ & $1.70 \pm 0.02$ & $5.79 \pm 0.07$ \\
\hline & $\% *$ & -33.9 & -19.3 & -29.2 & -20.9 & -18.3 & -10.9 \\
\hline \multirow{3}{*}{ Q. aliena } & Control & $2.96 \pm 0.01$ & $1.02 \pm 0.01$ & $3.98 \pm 0.02$ & $0.83 \pm 0.01$ & $2.90 \pm 0.01$ & $4.77 \pm 0.02$ \\
\hline & $150 \mathrm{ppb}$ & $2.20 \pm 0.01$ & $1.20 \pm 0.01$ & $3.40 \pm 0.01$ & $0.68 \pm 0.01$ & $1.83 \pm 0.01$ & $5.02 \pm 0.03$ \\
\hline & $\%$ & -25.7 & 17.7 & -14.9 & -18.1 & -36.9 & 5.2 \\
\hline \multirow{3}{*}{ Q.palustris } & Control & $2.70 \pm 0.01$ & $0.92 \pm 0.01$ & $3.62 \pm 0.01$ & $0.70 \pm 0.01$ & $2.93 \pm 0.01$ & $5.15 \pm 0.02$ \\
\hline & $150 \mathrm{ppb}$ & $2.29 \pm 0.02$ & $0.67 \pm 0.01$ & $2.96 \pm 0.02$ & $0.60 \pm 0.01$ & $3.44 \pm 0.02$ & $4.89 \pm 0.01$ \\
\hline & $\%$ & -15.2 & -27.2 & -18.2 & -14.3 & 17.4 & -5.1 \\
\hline \multirow{3}{*}{ Q. serrata } & Control & $3.73 \pm 0.06$ & $1.72 \pm 0.03$ & $5.45 \pm 0.05$ & $0.83 \pm 0.01$ & $2.17 \pm 0.06$ & $6.53 \pm 0.04$ \\
\hline & $150 \mathrm{ppb}$ & $3.10 \pm 0.02$ & $1.40 \pm 0.01$ & $4.50 \pm 0.02$ & $0.75 \pm 0.01$ & $2.21 \pm 0.02$ & $5.96 \pm 0.05$ \\
\hline & $\%$ & -16.9 & -18.6 & -17.4 & -9.6 & -1.8 & -8.7 \\
\hline \multirow{3}{*}{ Q. variabilis } & Control & $3.40 \pm 0.05$ & $1.67 \pm 0.01$ & $5.10 \pm 0.06$ & $0.83 \pm 0.06$ & $2.05 \pm 0.01$ & $6.18 \pm 0.03$ \\
\hline & $150 \mathrm{ppb}$ & $1.90 \pm 0.02$ & $1.25 \pm 0.01$ & $3.15 \pm 0.03$ & $0.60 \pm 0.01$ & $1.51 \pm 0.01$ & $5.28 \pm 0.02$ \\
\hline & $\%$ & -44.1 & -25.2 & -38.2 & -27.7 & -26.3 & -14.6 \\
\hline \multicolumn{2}{|c|}{ Species (S) } & $* * *$ & $* * *$ & $* * *$ & $* * *$ & $* * *$ & $* * *$ \\
\hline \multicolumn{2}{|c|}{ Ozone $\left(\mathrm{O}_{3}\right)$} & $* * *$ & $* * *$ & $* * *$ & $* * *$ & $* * *$ & $* * *$ \\
\hline \multicolumn{2}{|c|}{$\mathrm{S} \times \mathrm{O}_{3}$} & $* * *$ & $* * *$ & $* * *$ & $* * *$ & $* * *$ & $* * *$ \\
\hline
\end{tabular}

All the values are means of five replicates $\pm \mathrm{SD}$; mixed effects linear model: $* * * p<0.001$

$*$ Reduction rate $(\%)$ was calculated as: $\%=[($ control-treatment $) /$ control $] \times 100$.

control and ozone treatment for all five species and SD is the standard deviation of difference rate for five species. Standard index calculated by multiplied with weight value 12.5 to make even impact for all 8 parameters. The total sum of tolerance index that is calculated from 4 antioxidative enzymes and injury index including sum of MDA, chlorophyll content, carboxylation efficiency and biomass were aggregated to evaluate the tolerance against ozone stress.

\subsection{Statistical analysis}

To compare the effect on control and $\mathrm{O}_{3}$ treatment, ANOVA was performed on experimental data (statistical significance, $p \leq 0.05$ ). Statistical analyses were performed using the statistical package SAS System for Windows, Version 8.01 (SAS Institute, USA).

\section{RESULTS}

\subsection{Photosynthetic pigments}

After 28 day of ozone exposure, the contents of photosynthetic pigments showed significant $(p<0.05)$ dif- ferences among five species, between control and ozone treatment and species $\times$ ozone treatment interaction. Chlorophyll and carotenoid contents were decreased by ozone treatment, indicating that $\mathrm{O}_{3}$-exposed plants underwent physiological inhibition (Table 1). Ozone treatment negatively affected on the photosynthetic pigments in the leaves of five Quercus species. The content of chlorophyll $a$ in the seedlings of five species was $44.1 \%$ (Q. variabilis) to $15.1 \%$ (Q. palustris) lower in $\mathrm{O}_{3}$-exposed plant when compared with the control, respectively. For the content of chlorophyll $b, Q$. palustris and $Q$. serrata showed reduction rate ranged from $27.2 \%$ to $18.6 \%$, whereas $Q$. aliena showed an increase of $17.8 \%$ under ozone exposure. The reduction rate of total chlorophyll contents in five species ranged from $14.9 \%$ ( $Q$. aliena) to $38.2 \%$ (Q. variabilis) in $\mathrm{O}_{3}$ exposed plant comparing control, respectively. Carotenoid content showed highest reduction in $Q$. variabilis $(27.7 \%)$ and lowest reduction in Q. serrata (9.5\%) under ozone fumigation. The highest reduction rate on the ratio of chlorophyll $a$ to chlorophyll $b$ was observed in the leaves of $Q$. aliena (38.9\%), whereas $Q$. palustris 
increased by $17.4 \%$ under ozone exposure, respectively. For the ratio of total chlorophyll to carotenoid,

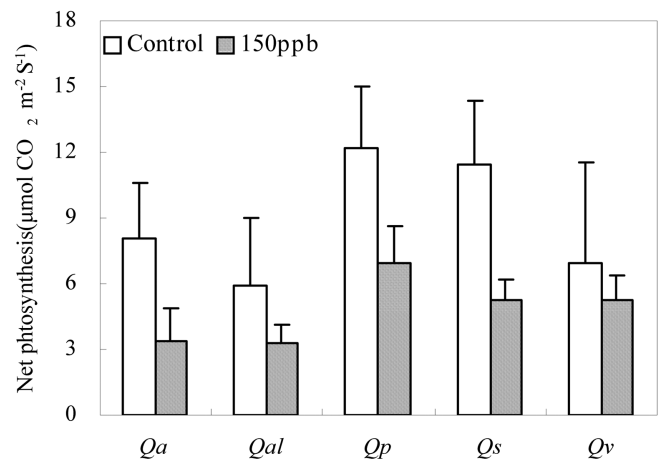

A
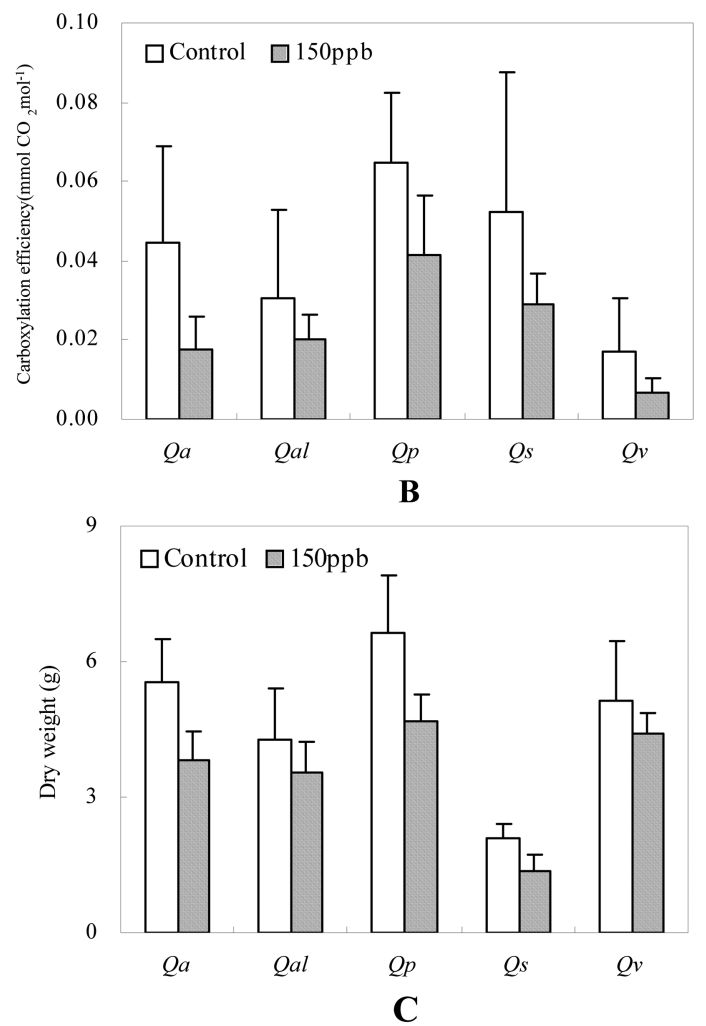

Fig. 1. Effects of ozone fumigation on net photosynthesis, carboxylation efficiency and biomass in the leaves of five species of genus Quercus. Qa: Q. acutissima, Qal: Q. aliena, $Q p: Q$. palustris, $Q s: Q$. serrata, and $Q v: Q$. variabilis. All the values are means of five replicates $\pm \mathrm{SD}$; mixed effects linear model. Net photosynthesis: species $p=0.0003^{* * *}$, ozone $p=$ $0.0001^{* * *}$, species $\times$ ozone $p=0.2213$; carboxylation efficiency: species $p=0.0001^{* * *}$, ozone $p=0.0006^{* * *}$, species $\times$ ozone $p=0.7530$; dry weight: species $p<0.0001^{* * *}$, ozone $p<0.0001^{* * *}$, species $\times$ ozone $p=0.2626{ }^{*}{ }^{* *}$ and ${ }^{* * *}$ significant at $p \leq 0.05,0.01$ and 0.001 .
Q. variabilis showed highest reduction (14.6\%).

\subsection{Net photosynthesis, carboxylation efficiency and biomass}

The net photosynthesis showed significant $(p<0.05)$ differences among species and between control and ozone treatment at the end of ozone exposure (Fig. 1). However, there was no significant interaction between species and ozone treatment for net photosynthesis. The reduction rate of net photosynthesis comparing with control in the seedlings of five species varied from $23.8 \%$ (Q. variabilis) to $58.6 \%$ (Q. acutissima). Carboxylation efficiency differed significantly $(p<0.05)$ among species and between control and ozone treatment at the end of ozone exposure (Fig. 1). Species $\times$ ozone treatment interaction was not significant for carboxylation efficiency in the seedlings of five species. The reduction rate of carboxylation efficiency was the highest in the leaves of $Q$. acutissima $(62.1 \%)$, and $Q$. aliena that showed lowest reduction rate was also decreased $33.6 \%$ for carboxylation efficiency in comparison with control. Substantial progression of photosynthetic-pigment destruction by ozone fumigation suggested the hinder of photosynthesis and decrees of photosynthesis resulted in reduction of biomass. Biomass showed the same result with net photosynthesis and carboxylation efficiency. There were significant $(p<$ $0.05)$ differences among species and between control and ozone treatment while there was no significant difference with species $\times$ ozone treatment interaction. Among five species, $Q$. acutissima (30.9\%) and $Q$. ser-

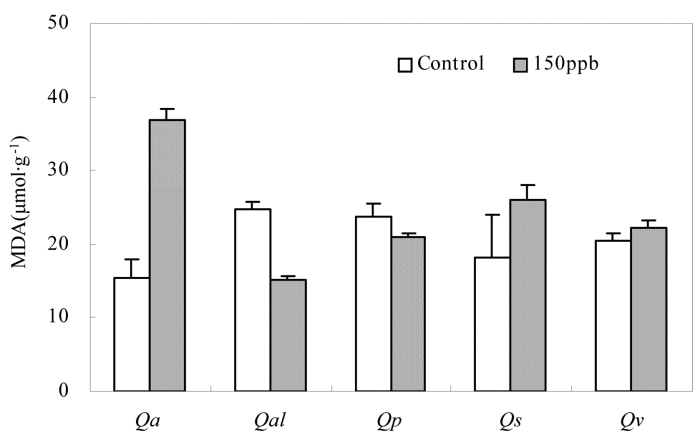

Fig. 2. Effect of ozone fumigation on MDA content in the leaves of five species of genus Quercus. Qa: Q. acutissima, Qal: $Q$. aliena, $Q p: Q$. palustris, $Q s Q$. serrata, and $Q v: Q$. variabilis. All the values are means of five replicates $\pm \mathrm{SD}$; mixed effects linear model. Species $p=0.0001^{* * *}$, ozone $p=0.0001^{* * *}$; species $\times$ ozone $p=0.0001^{* * *}$ significant at $p$ $\leq 0.001$. 
Table 2. Effects of ozone fumigation on antioxidative enzyme activities in the leaves of five species of genus Quercus

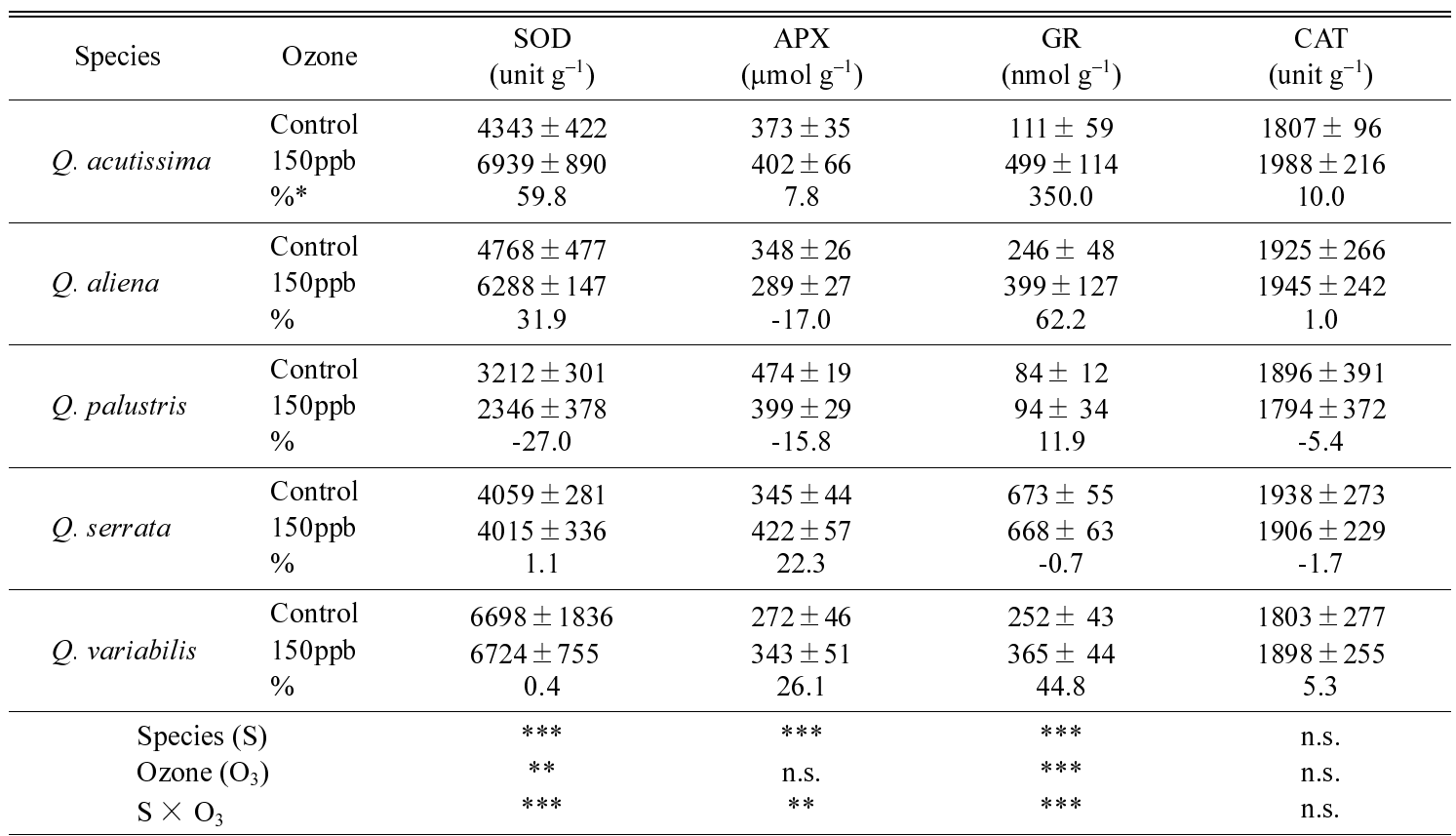

All the values are means of five replicates $\pm \mathrm{SD}$; mixed effects linear model: $* * p<0.05, * * * p<0.001$, and n.s.: not significant. *Increasing rate $(\%)$ was calculated as: $\%=[($ control-treatment $) /$ control $] \times 100$

rata $(33.3 \%)$ showed high reduction and $Q$. variabilis $(14.0 \%)$ showed low reduction in biomass.

\subsection{Lipid peroxidation and antioxidative enzyme} activity

There was a significant difference in leaf MDA content among five species and between control and ozone treatment (Fig. 2). Especially, the amount of MDA was increased under ozone fumigation and showed the highest increase rate of $140 \%$ in $Q$. acutissima among five species, whereas it was reduced in $Q$. aliena and $Q$. palustris under ozone fumigation.

The responses of antioxidative enzymes varied each other under ozone fumigation (Table 2). For SOD, there was a significant $(p<0.05)$ difference among five species. There was a significant difference between control and ozone treatment, and species $\times$ ozone treatment interaction showed a significant difference for SOD activity. $Q$. acutissima showed the highest increase rate of SOD activity (59.8\%), however, $Q$. palustris showed highest reduction of SOD activity (-27\%). APX activity differed significantly $(p<0.05)$ between control and ozone treatment as well as among five species, and species $\times$ ozone treatment interaction was also significant for APX activity. APX activity increased in

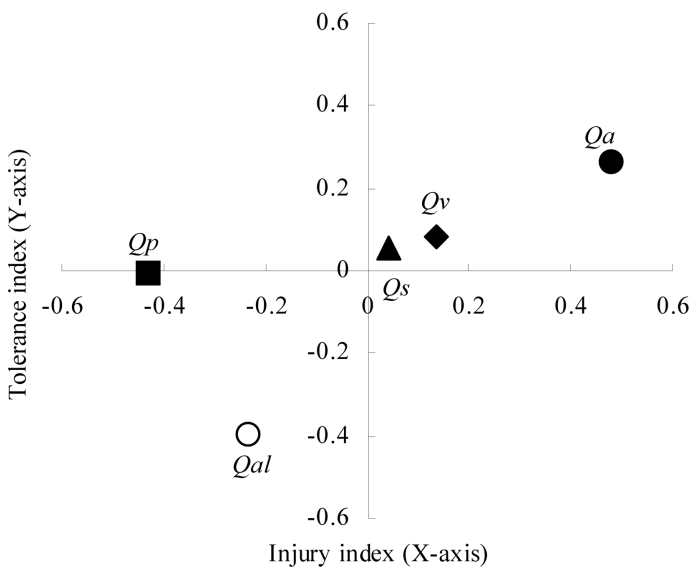

Fig. 3. Correlation of tolerance and injury indices. Data for this figure were obtained from the same measurements as in Tables 1, 2 and Figs. 1, 2. Quercus Qa: Q. acutissima, Qal: $Q$. aliena, $Q p: Q$. palustris, $Q s: Q$. serrata, and $Q v: Q$. variabilis. The differences between the values of exposed ozone and unexposed ozone on photosynthetic pigment content, photosynthesis, biomass and MDA content were evaluated for injury index, and four antioxidative enzyme activities were used for tolerance index.

the leaves of $Q$. acutissima (7.8\%), Q. serrata $(22.3 \%)$ and $Q$. variabilis $(26.1 \%)$ under ozone exposure, whereas 
Q. aliena (-17.0\%) and Q. palustris $(-15.8 \%)$ decreased in comparison with control plants. GR activity differed significantly $(p<0.05)$ between control and ozone treatment as well as among five species, and species $\times$ ozone treatment interaction was also significant for GR activity. GR activity remarkably increased in the leaves of $Q$. acutissima (350\%) and Q. aliena $(62.2 \%)$ under ozone exposure. However, Q. serrata showed no significant difference in comparison with control plants. For CAT activity, the differences among species, treatments and species $\times$ ozone interaction were not significant.

\subsection{Rank of tolerance ability using tolerance and injury index}

Based on physiological and biochemical responses mentioned above, ozone tolerance ability of five Quercus species was ranked as $Q$. aliena $>Q$. palustris $>Q$. serrata $>Q$. variabilis $>Q$. acutissima (Fig. 3).

\section{DISCUSSION}

In our research, the degree of ozone-injury was quantitatively estimated and compared among five oak species, based on four injury and four tolerance indices. A gradient in $\mathrm{O}_{3}$ sensitivity was found for the species involved in this experiment. The results indicate that the differences between control and treatment in the sensitivity to ozone were distinct in aspects of low levels of chlorophyll and carotenoid content of $\mathrm{O}_{3}$-fumigated leaves (Table 1). Reduction in the chlorophyll content of leaves, following exposure of plants to ozone, has been reported in many species such as Pinus ponderosa (Anderson et al., 2003), Acer species (Han et al., 2007), Citrus (Iglesias et al., 2006) and Quercus ilex (Ribas et al., 2005). Knudson et al. (1977) and Sakaki et al. (1983) found higher reduction in chlorophyll $a$ than chlorophyll $b$ in $\mathrm{O}_{3}$-exposed plants of Phaseolus vulgaris L. and Spinacia oleracea L. and our results also support this founding (Table 1). Ozone exposure induces the activation of leaf senescencerelated process that was linked to chlorophyll degradation, photosynthetic decline and lipid peroxidation (Ribas et al., 2005; Bielenberg et al., 2002).

The most apparent effect of oxidative stress induced by ozone described in numerous species, is leaf damage. In our experiments, visible injury symptoms (i.e., dark pigmented stipple in $Q$. serrata, brown pigmented stipple in $Q$. palustris and necrosis in Q. acutissima) were observed in $\mathrm{O}_{3}$-treated plants. It has been reported that a main detrimental effect of ozone at the subcellular level is photosystem damage and reductions in photosynthesis (Anderson et al., 2003), and collapse of mesophyll cells (Long and Naidu, 2002)

Adult holm oaks (Q. ilex) may be considered to be $\mathrm{O}_{3}$ tolerant in terms of photosynthesis, as only $9 \%$ reduction was recorded in the $\mathrm{O}_{3}$-treated leaves compared to the controls (Paoletti et al., 2007) and also, Felzer et al. (2007) reported higher sensitivity to ozone in 30-yearold mature trees than two year-old seedlings due to greater photosynthetic rates leading to higher stomatal conductances in the older trees. However, we observed severe reduction rate of net photosynthesis ranging from $23.8 \%$ to $58.6 \%$, and carboxylation efficiency ranging from $33.6 \%$ to $62.1 \%$ by ozone treatment for all five species in spite of one-year-old seedlings. Photosynthesis reduction leads to growth and biomass reduction, and reduction rate ranged from $14 \%$ to $33.3 \%$ (Fig. 1A, 1B, and 1C). Vitale et al. (2008) showed severely limited photosynthesis in three-year-old seedling of $Q$. ilex by $250 \mathrm{ppb}$ of $\mathrm{O}_{3}$ fumigation like our results. Therefore, the reasons of differential results about photosynthesis and biomass to $\mathrm{O}_{3}$ tolerance could be variance among species or difference of $\mathrm{O}_{3}$ concentration.

We analyzed the level of lipid peroxidation and antioxidant activity, including SOD, APX, GR, CAT, because each of these traits have been previously associated with oxidative stress induced by $\mathrm{O}_{3}$ (Puckette $e t$ al., 2007; Iglesias et al., 2006). MDA concentration, which estimates the state and integrity of membrane through the degree of lipid peroxidation, has been shown to correlate with the level of ozone exposure. In addition, $\mathrm{O}_{3}$-treated plants showed an increase in MDA content, indicating the state of membrane lipid peroxidation has a correlation with the degree of $\mathrm{O}_{3}$ exposure to plants (Prince et al., 1990; Yoshida et al., 1994; Ranieri et al., 1996; Iglesias et al., 2006). In our results, there was the increase of MDA content after exposure of $\mathrm{O}_{3}$ in $Q$. acutissima, Q. serrata and $Q$. variabilis species that showed severe reduction of chlorophyll content and net photosynthetic rate. However, the other two species, $Q$. aliena and $Q$. palustris, which showed no reduction rate in the ratio of chlorophyll $a$ to $b$, did not increase in MDA content (Fig. 2). Therefore, the reduction of chlorophyll content and net photosynthesis had a tendency of the increase of MDA content in sensitive species. 
Lipid peroxidation is the ultimate effect of $\mathrm{O}_{3}$ attack to membranes, once the antioxidant defenses of membranes fail to cope with $\mathrm{O}_{3}$ and oxygen radicals (Calatayud et al., 2002; Iglesias et al., 2006). Plant responds to $\mathrm{O}_{3}$-induced oxidative stress by activation of a number of antioxidative stress-related defense mechanisms. Carotenoid is also protective agents against oxidative stress, and has been associated with photoprotective mechanisms and ascorbate pool that plays a crucial role to the defense of hydrogen peroxides reaction (Tauz et al., 2002; Iglesias et al., 2006). However, in our study, we did not find a concomitant decrease in both carotenoid content and antioxidative enzyme activities.

In the present study, there were significant differences in the activities of SOD and GR between treatments. On the contrary, APX and CAT had no significant differences between treatments. SOD and APX activities were higher in $\mathrm{O}_{3}$-treated $Q$. palustris than those of control plants, whereas GR activities were not significantly increased (Table 2). Additionally, Q. acutissima that showed high reduction rate in photosynthetic pigments content, photosynthesis and highest increase rate of MDA content had highest increase rate in SOD and GR activities (see above). Although cellular responses to ozone are dependent on multiple factors, in general higher activities of scavenger antioxidant metabolite usually increase protection against stress (Sharma and Davis, 1997; Calatayud et al., 2002; Iglesias et al., 2006). In our experiment, sensitive species induced increase of APX activity, on the other hand, it was decreased in tolerance Quercus species (Q. aliena and Q. palustris). APX is a component of ascorbate-glutathione pathway and both chloroplast and cytosolic isozymes of APX. Elevated APX activities in $\mathrm{O}_{3}$ treated plants contribute to tolerance against $\mathrm{O}_{3}$ through the removal of $\mathrm{H}_{2} \mathrm{O}_{2}$ by APX. SOD represents another major class of antioxidant enzymes that play an important role in eliminating $\mathrm{O}_{2}$ during oxidative stress. No difference in total SOD and GR mRNA amount and enzyme activity levels were observed in which plants were treated with $150 \mathrm{ppb} \mathrm{O}_{3}$. However, different ecotype plants of Arabidopsis thaliana exposed to 200 ppb $\mathrm{O}_{3}$ had higher $83 \%$ SOD activity and 98\% GR activity than controls (Sharma and Davis, 1997). No detectable changes in CAT activity were observed in $\mathrm{O}_{3}$-treated plants (Kubo et al., 1995; Rao et al., 1996). Sharma and Davis (1997) concluded that differences in these results were due to the dissimilar ecotypes used and the $\mathrm{O}_{3}$ treatments. As indicated in the previous studies, we may assume that APX, SOD and GR activities were highly connected with $\mathrm{O}_{3}$ induced stress in sensitive species as much as their activities highly increased. However, the $150 \mathrm{ppb} \mathrm{O}_{3}$ treatment for tolerance species did not alleviate the oxidative stress or those enzymes already used detoxification as defensive response. We also may not observe changes in CAT activities in $\mathrm{O}_{3}$-treated plants. Our data indicate that the exposure of five Quercus species to high ozone levels (150 ppb) altered several physiological parameters, and antioxidant mechanisms were triggered especially in sensitive species.

$\mathrm{O}_{3}$-induced physiological and biochemical responses can be used as a valuable criterion to rank the sensitivity of these species to the ozone pollutant (Fig. 3). Among five species, $Q$. acutissima was the most sensitive species that has detrimental effects on its highest reduction rate of chlorophyll, net photosynthesis and carboxylation efficiency, and highest increase rate of lipid peroxidation by ozone fumigation in our research. Therefore, in conclusion, the results of this experiment support three-tested hypotheses. Ozone exposure enhanced leaf senescence-related processes and induced reduction of chlorophyll content, photosynthetic decline and depletion of biomass accumulation. Our present study suggests that 1) physiological markers such as chlorophyll contents, photosynthesis, MDA content and antioxidative enzymes were considered as the very important indicators in order to evaluate the tolerance against ozone stress, and 2) parameters were closely related with each other and thus they cannot be used as a single marker. The results of this study highlight the species specificity of ozone responses.

\section{적 요}

오존에 노출된 참나무속 5 종의 오존에 대한 내성 능 력을 평가하기 위하여 생리생화학적 변화를 조사하였 다. $150 \mathrm{ppb}$ 오존에 노출된 참나무속 5 종(상수리나무, 갈참나무, 대왕참나무, 졸참나무, 굴참나무)의 잎에서 엽록소 함량, 광합성 특성, MDA 함량 및 항산화효소 활성이 측정되었다. 엽록소, 카로테노이드 함량, 순광합 성 속도 및 탄소고정효율은 오존 처리 후에 감소하였 다. 오존에 노출된 수목의 총 엽록소 함량과 탄소고정 효율의 감소율은 갈참나무의 경우 $15 \%$ 와 $34 \%$ 였으 며, 굴참나무의 경우 $38.3 \%$ 와 $62.1 \%$ 였다. MDA 함 량은 오존 처리 하에서 증가하였으며, 상수리나무에서 $140 \%$ 까지 증가를 보였다. 상수리나무의 SOD 활성 증 
가율 $(60 \%)$ 은 가장 높았으며, $\mathrm{APX}$ 활성은 굴참나무, 졸참나무, 상수리나무에서 증가를 보였다. 생리생화학 적 반응을 기초로 한 참나무속 5 종의 내성 능력은 갈 참나무, 대왕참나무, 졸참나무, 굴참나무, 상수리나무 순이었다. 결론적으로 엽록소 함량, 광합성 특성, $\mathrm{MDA}$ 함량, 항산화효소와 같은 생리학적 지표들은 오 존 스트레스에 대한 내성을 평가하기 위한 매우 중요 한 지표들로 생각되며, 이러한 모수들은 서로 밀접한 관계를 가진다.

\section{REFERENCES}

Alonso, R., S. Elvira, F. J. Castillo, and B. S. Gimeno, 2001: Interactive effects of ozone and drought stress on pigments and activities of antioxidative enzymes in Pinus halepensis. Plant, Cell \& Environment 24, 905-916.

Anderson, P. D., B. Palmer, J. L. J. Houpis, M. K. Smith, and J.C. Pushnik, 2003: Chloroplastic responses of ponderrosa pine (Pinus ponderosa) seedlings to ozone exposure. Environment International 29, 407-413.

Beauchamp, C. and I. Fridovich, 1971: Superoxide dismutase: Improved assays and an assay applicable to acrylamide gels. Analytical Biochemistry 44, 276-297.

Bielenberg, D. G., J. P. Lynch, and E. J. Pell, 2002: Nitrogen dynamics during $\mathrm{O}_{3}$-dincuded accelerated senescence in hybrid polar. Plant, Cell \& Environment 25, 501-512.

Calatayud, Á., J. W. Ramirez, H. D. Iglesias, and E. Barreno, 2002: Effects of ozone on photosynthetic $\mathrm{CO}_{2}$ exchange, chlorophyll a fluorescence and antioxidant systems in lettuce leaves. Physiologia Plantarum, 116, 308316.

Carlberg, I. and B. Mannervik, 1985: Glutathione reductase. Methods in Enzymology 113, 485-490.

Elvira, S., R. Alonso, F. J. Castillo, and B. S. Gimeno, 1998: On the response of pigments and antioxidants of Pinus halepensis seedlings to Mediterranean climatic factors and long-term ozone exposure. New Phytologist 138, 419-432.

Elvira, S, V. Bermejo, E. Manrique, and B. S. Gimeno, 2004: On the response of two populations of Quercus coccifera to ozone and its relationship with ozone uptake. Atmospheric Environment. 38, 2305-2311.

Farquhar, G.D., von S. Caemmerer, and J.A. Berry, 1980: A biochemical model of photosynthetic $\mathrm{CO}_{2}$ assimilation in leaves of $\mathrm{C}_{3}$ species. Planta 149, 78-90.

Fossati, P., L. Prencipe, and G. Berti, 1980: Use of 3,5dichloro-2-hydroxy benzenesulfonic acid /4-aminophenazone chromogenic system in direct enzyme assay of uric acid in serum and urine. The Clinical Chemistry Methodology 26, 227-231.
Felzer, B. S., T. Cronin, J. M., Reilly, J. M. Melillo, and X. Wang, 2007: Impacts of ozone on trees and crops. Comptes Rendus Geoscience 339, 784-798.

Fuhrer, J. and B. Achermann, 1994: Critical levels for ozone; AUN-ECE Workshop report. FAC Report No. 16 Swiss federal research station for Agricultural Chemistry and Environmental Hygience, Liebefeld-Bern.

Han, S. H., D. H., Kim, K. Y. Lee, J .J. Ku, and P. G. Kim, 2007: Physiological damages and biochemical alleviation to ozone toxicity in five species of genus Acer. Journal of Korean Forest Society 96, 551-560.

Han, S. H., J. C. Lee, W. Y. Lee, Y. Park, and C. Y. Oh, 2006: Antioxidant characteristics and phytoremediation potential of 27 texa of roadside trees at industrial complex area. Korean Horticultural of Agricultural and Forest Meteorology 8, 159-168.

Hanson, P. J., S. D. Wullschleger, R. J. Norby, T. J. Tschaplinski, and C. A. Gunderson, 2005: Importance of changing $\mathrm{CO}_{2}$, temperature, precipitation, and ozone on carbon and water cycles of an upland-oak forest: incorporating experimental results into model simulations. Global Change Biology 11, 1402-1423.

Hanson, P. J., L. J. Samuelson, and S. D. Wullschleger, 1994: Seasonal patterns of light-saturated photosynthesis and leaf conductance for mature and seedling Quercus rubra L. Foliage: differential sensitivity to ozone. Tree Physiology 14, 1351-1366.

Heath, R. L. and L. Parker, 1968: Photoperoxidation in isolated chloroplasts. I. Kinetics and stoichiometry of fatty acid peroxidation. Archives of Biochemistry and Biophysics 125, 189-198.

Iglesias, D. J., Á. Calatayud, Barreno, E. Primi-Millo, and M. Talon, 2006. Responses of citrus plants to ozone: leaf biochemistry, antioxidant mechanisms and lipid peroxidation. Plant Physiology and Biochemistry 44, 125-131.

Inclán, R., A. Ribas, M. Pujadas, J. Teres, and B. S. Gimeno, 1999: The relative sensitivity of different Mediterranean plant species to ozone exposure. Water, Air, and Soil Pollution 116, 273-277.

Karnosky, D. F., J. M. Skelly, K. E. Percy, and A. H. Chappelka, 2007: Perspectives regarding 50 years of research on effects of tropospheric ozone air pollution on US forests. Environmental Pollution 147, 489-506.

Kelting, D. L., J. A. Burger, and G. S. Edwards, 1995: The effects of ozone on the root dynamics of seedlings and mature red oak (Quercus rubra L.). Forest Ecology and Management 769, 197-206.

Kim, P. G., and E. J. Lee, 2001: Ecophysiology of photosynthesis 1: Effects of light intensity and intercellular $\mathrm{CO}_{2}$ pressure on photosynthesis. Korean Journal of Agricultural and Forest Meteorology 3, 126-133.

Knudson, L. L., T. W. Tibbitts, and G. E., Edwards, 1977: Measurement of ozone injury by determination of leaf chlorophyll concentration. Plant Physiology 60, 606- 
608

Kubo, A., H., Saji, K. Tanaka, and N. Kondo, 1995: Expression of Arabidopsis cytosolic ascorbate peroxidase gene in response to ozone or sulfur dioxide. Plant Molecular Biology 29, 479-489.

Long, S. P., and S. P. Naidu, 2002: Effects of oxidants at the biochemical, cell and physiological levels, with particular reference to ozone. Air pollution and plant Life, J. N. B. Bell, and M. Treshow (Eds.), Wiley, London, 6988.

Lichtenthaler, H. K., 1987: Chlorophylls and carotenoids: pigments of photosynthetic biomembranes. Methods in Enzymology 148, 350-382.

Lee, J. C., S. H. Han, P. G. Kim, S. S. Jang, and S. Y. Woo, 2003: Growth, physiological responses and ozone uptake of five Betula species exposed to ozone. Korean Journal of Ecology 26, 165-172.

Mills, G., G. Ball, F. Hayes, J. Fuhrer, L., Skarby, L., B. Gimeno. L. De Temmerman, and A. Heagle, 2000: Development of a multi-factor model for predicting the effects of ambient ozone on the biomass of white clove. Environmental Pollution 109, 533-542.

Ministry of Environment, 2005: Annual report of air quality in Korea 2004, 145pp.

Minnocci, A., A. Pannicucci, L. Sebastiani, G. Lorenzini, and C. Vitagliano, 1999: Physiological and morphological responses of olive plants to ozone exposure during a growing season. Tree Physiology 19, 391-397.

Müller-Edzards, C., W. De Nries, and J. W. Erisman, 1997: Ten years of monitoring forest condition in Europe. UN/ ECE-EC Technical Background Report. Brussels, Geneva: EC-UN/ECE

Nakano, Y., and K. Asada, 1981: Hydrogen peroxide is scavenged by ascorbate-specific peroxidase in spinach chloroplasts. Plant Cell Physiology 22, 867-880.

Pääkkönen, E., J. Vahala, M. Pohjola, T. Holopainen, and L. Kärenlampi, 1998: Physiological, stomatal and ultrastructural ozone responses in birch (Betula pendula Roth) are modified by water stress, Plant, Cell \& Environment 21, 671-684.

Paoletti, E., C. Nali, R. Marabottini, G. Della Rocca, G. Lorenzini, A. R. Paolacci, M. Ciaffi, and M. Badiani, 2003: Strategies of response to ozone in Mediterranean evergreen species. Establishing Ozone Critical Levels II. UNECE Workshop Report. IVL report B 1523, IVL Swedish Environmental Research Institute, Göteborg, Sweden, 336-343.

Paoletti, E., G. Seufert, G. Della Rocca, and H. Thomsen, 2007: Photosynthetic responses to elevated $\mathrm{CO}_{2}$ and $\mathrm{O}_{3}$ in Quercus ilex leaves at a natural $\mathrm{CO}_{2}$ spring. Environmental Pollution 147, 516-524.

Prince, A., P. W. Lucas, and P. J. Lea, 1990: Age dependent damage and glutathione metabolism in ozone fumigated barley: a leaf section approach. Journal of
Experimental Botany 41, 1309-1317.

Puckette, M. C., H. Weng, and R. Mahalingam, 2007: Physiological and biochemical responses to acute ozoneinduced oxidative stress in Medicago truncatula. Plant Physiology and Biochemistry 45, 70-79.

Ranieri, A., G. D’Urso, C., Nali, G. Lorenzini, and G. F. Soldatini, 1996: Ozone stimulates apoplastic antioxidant systems in pumpkin leaves. Physiologia Plantarum 97, 381-387.

Ranieri, A., G. Ginuntini, F. Ferraro, C., Nali, B., Baldan, G. Lorensini, and G.R. Soldatini, 2001: Chronic ozone fumigation induces alterations in thylakoid functionality and composition in two poplar clones. Plant Physiology and Biochemistry 39, 999-1008.

Ragazzi, A., S. Moricca, and I. Dellavalle, 1998: Status of oak decline studies in Italy and some view of the European situation. Proceedings of Workshop on Disease/ Environment Interactions in Forest Decline, Vienna, Austria, 202.

Rao, M. V., C. Paliyath, and D. P. Ormrod, 1996: Ultraviolet-B and ozone-induced biochemical changes in antioxidant enzymes of Arabidopsis thaliana. Plant Physiology 110, 125-136.

Ribas, À., J. Peñuelas, S. Elvira, and B. S. Gimeno, 2005: Ozone exposure induces the activation of leaf senescence-related processes and morphological and growth changes in seedlings of Mediterranean tree species. Environmental Pollution 134, 291-300.

Sakaki, T., N. Kondo, and K. Sugahara, 1983: Breakdown of photosynthetic pigments and lipids in spinach leaves with ozone fumigation: role of active oxygens. Physiologia Plantarum 59, 28-34.

Samuelson, L. J., J. M. Kelly, and P. A. Mays, 1996: Growth and nutrition of Quercus rubra L. seedlings and mature trees after three seasons of ozone exposure. Environmental Pollution 91, 317-323.

Sharma, Y. K. and K. R. Davis, 1997: The effects of ozone on antioxidant responses in plants. Free Radical Biology \& Medicine 23, 480-488.

Skärby, L., H. Ro-Poulsen, F. A. M. Wellburn, and L. J. Sheppard, 1998: Impacts of ozone on forests: a European perspective. New Phytologist 139, 109-122.

Sousa Santos, M. N. D, and A. M. Moura Martins, 1993: Cork oak decline. Notes regarding damage and incidence of Hypexylon mediterraneum. Recent advances in Studies on Oak Decline. N.P. Luisi, A. Lerario, and B. Nannini (Eds), Italy: Universita degli Studi, Dipartmento di by Patologia vegetale, 115-121.

Tauz, M., K. Herbinger, S. Posch, and N. E. Grulke, 2002: Antioxidant status of Pinus jeffreyi needles from mesic and xeric microsites in early and late summer. PhytonAnnales Rei Botanicae 42, 201-207.

Thomas, F. M., R. Blank, and G. Hartmann, 2002: Abiotic and biotic factors and their interactions as causes of oak 
decline in Central Europe. Forest Pathology 32, 277307.

Vitale, M., E. Calvatori, F. Voreto, S. Fares, and F. Manes, 2008: Physiological responses of Quercus ilex leaves to water stress and acute ozone exposure under controlled conditions. Water, Air, and Soil Pollution 189, 113-125.

Weinstein, A., L. J. Samuelson, and M. A. Arthur, 1998: Comparison of the response of red oak (Quercus rubra) seedlings and mature trees to ozone exposure using simulation modeling. Environmental Pollution 102, 307320.

Wullschleger, S. D., P. J. Hanson, and G. S. Edwards, 1996:
Growth and maintenance respiration in leaves of northern red oak seedlings and mature trees after three years of ozone exposure. Plant Cell and Environment 19, 577584.

Yoshida, M., Y. Nouchi, and S. Toyama, 1994: Studies on the role of active oxygen in ozone in injury to plant cells. I. Generation of active oxygen in rice protoplast exposed to ozone. Plant Science 95, 197-205.

Zheng, Y., H. Shimizu, and J. D. Barnes, 2002: Limitations to $\mathrm{CO}_{2}$ assimilation in ozone-exposed leaves of Plantago major. New Phytologist 155, 67-78. 